\title{
The case of Johannesburg water: What really happened at the pre-paid 'Parish pump'
}

\author{
PATRICK BOND \\ Centre for Civil Society (CCS), University of KwaZulu-Natal \\ JACKIE DUGARD \\ Centre for Applied Legal Studies (CALS), University of the Witwatersrand
}

\section{INTRODUCTION}

At around two o'clock in the morning on 27 March 2005, Phiri resident Vusimuzi Paki awoke to the shouts of a tenant who was trying to put out a fire in one of the other backyard shacks on Paki's property. Assisted by neighbours, the first crucial minutes were spent trying to extinguish the fire using the pre-paid water meter supply that the Johannesburg Water company had recently installed to control the residents' water supply. However, the water pressure was insufficient to make much impact on the fire and, after a while, the pre-paid meter water supply automatically disconnected due to insufficient water credit. Residents were then forced to scoop up ditch water with buckets in a desperate attempt to put out the fire. More minutes passed. One neighbour tried to telephone the police at Moroka police station but no-one answered the phone. After battling for an hour, residents finally put out the fire, but not before the shack had burnt to the ground. It was only after Paki's tenant returned home from her night shift that everyone discovered to their horror that her two small children had been sleeping in the shack. They both died in the fire.

Paki's story highlights the life and death importance of pre-paid water meters. Beyond this tragic incident are other durable water problems: the daily indignity and inhumanity that people in Phiri (one of the poorest areas of Soweto) have had to endure since Johannesburg Water installed pre-paid meters as a cost-recovery measure, starting in 2004, and the prohibitively expensive price charged for subsequent water consumption. As Paki's neighbour Jennifer Makoatsane can attest, Johannesburg Water's cost-recovery has come at the expense of Phiri residents' basic needs and their constitutionally-guaranteed human rights. Like most Phiri residents, Makoatsane is unemployed and desperately poor. She lives on a property with nine other people, some in her main house and others in backyard shacks. Because the City's "Free Basic Water" (FBW) supply is allocated per stand and only to property-owning account-holders, Makoatsane must share the one allocation with all nine people. With so many people sharing the water, the monthly 
6000 litre -6 kilolitres (6kl), roughly the volume of one minibus taxi - free allocation never lasts to the end of the month, even though household members now flush the toilet only once a day and bathe only every second day. Since the advent of the pre-paid meters, once the FBW allocation is exhausted (usually around the $12^{\text {th }}$ day of the month), the pre-paid water meter automatically disconnects the water supply until further water credit is purchased. However, in households like Makoatsane's, where there is rarely enough money to purchase sufficient water to ensure an adequate supply for the month, the automatic disconnection typically signals no water supply at all until the next month's FBW allocation is loaded and dispensed.

The automatic disconnection feature of pre-paid meters is unusual and it does not occur in conventional meters (found elsewhere in Johannesburg), which provide important procedural protections prior to any disconnection of the water supply. These protections - the purchase of water on credit with reasonable notice of being in arrears and of possible disconnection, along with an opportunity to make representations before there is a disconnection - are in place in conventional water supplies precisely to avoid the Phiri situation, where people are forced to go without water for days at a time because of circumstances beyond their control, including abject vulnerability and poverty. Yet, while people in Johannesburg's richer suburbs with conventional meters continue to enjoy substantive protections prior to water disconnection, ${ }^{1}$ poverty-stricken people in Phiri with pre-paid meters have been forced to forgo such procedural protections - their water supply terminates automatically and immediately on exhaustion of the FBW or credit supply.

Determined to enjoy the same rights as rich people despite their poverty, in July 2006 Paki and Makoatsane, along with three other Phiri residents, formally launched an application challenging the constitutionality and lawfulness of pre-paid water meters and the sufficiency of the FBW allocation. ${ }^{2}$ The case, Mazibuko \& Others $v$ the City of Johannesburg \& Others, was heard in the Johannesburg High Court between 3 and 5 December 2007. The decision was handed down as this article was about to be published, on 30 April 2008. In a judgment groundbreaking for its sensitivity towards the lives of the poor and for the use of human rights as a mechanism to advance socioeconomic transformation in South Africa, High Court Judge Moroa Tsoka ruled in favour of the applicants. Finding the "prepayment water system in Phiri Township" to be "unconstitutional and unlawful", the judge ordered

1 In terms of bylaw $9 \mathrm{c}$ of the City of Johannesburg Metropolitan Municipality Water Services By-Laws (28 April 2004), where a "consumer" with a conventional meter "fails to pay the amount due", the council "may only discontinue supply to a consumer in arrears" after pursuing all of the following specific procedures: a "final demand notice", the "opportunity to conclude an agreement with the Council for payment of the arrears amount in installments within 14 days of the date of the final demand notice", and hand delivering or posting to the last recorded address a "final discontinuation notice informing such consumer that the provision of water services will be discontinued".

2 Although the application was formally launched in the Johannesburg High Court in July 2006, the litigation process began in 2004, with letters of demand to Johannesburg Water. The length of time it took for the case to be launched in court is an indication of how difficult it is (especially for civil society organisations and social movements) to mount a socio-economic rights case. In the end, the application comprised over 6000 pages of record, filling some 20 lever arch files. 
the City to provide each applicant, and all other similarly placed residents of Phiri Township, with a "free basic water supply of 50 litres per person per day and the option of a metered supply installed at the cost of the City of Johannesburg". ${ }^{3}$ Although this judgment is likely to be appealed by the City, and notwithstanding the ultimate outcome following an inevitably lengthy appeals process, the legal arguments advanced by the parties highlight important ideological fault lines between a progressive rights-based approach to water delivery on the one hand and a cost-recovery imperative on the other hand, which are worth examining.

The Phiri case is the first South African case in which the applicants have explicitly sought enforcement of their constitutional right of access to sufficient water (section 27(1)(b) of the Constitution). ${ }^{4}$ For the applicants and their support organisations, the case has always been of critical importance in securing the constitutionally-guaranteed socio-economic rights of poor people. But, as explored in this article, the case also highlights the overall bias of water policy towards neoliberal characteristics. Yet, as appreciated by the applicants, critique is not enough; a strong set of alternative policy solutions should be considered, particularly in view of the courts' reluctance to secondguess policies, especially where no concrete alternatives are offered. With this in mind, the Phiri applicants specifically asked for (and were granted by the Tsoka judgment of 30 April 2008) a FBW supply of 50 litres per person per day (not 6000 litres per household per month), and the option of the kind of conventional metered water supply that exists throughout Johannesburg's richer suburbs.

Moreover, their case represents a much greater challenge to neoliberalism: a refutation of the "politics of the parish pump" thesis - to borrow the phraseology of former Department of Water Affairs and Forestry (DWAF) director general Mike Muller - that blames local victims (including underfunded municipalities and civil society protesters) for national and global neoliberal policy creep. At a time when the rate of demonstrations (under the Regulation of Gatherings Act 205 of 1993) recorded by SA Police Services was rising from around 6000 peryear (2004-05) to 10000 per year (2005-07), ${ }^{5}$ President Thabo Mbeki specifically remarked, "If this problem of lack of capacity in municipal governance is not given the necessary attention, it can undermine our efforts to deepen democracy at the local level. (It) may bring about an unintended consequence of the development of a gulf between our municipal governments and the people."6

3 Mazibuko \& Others $v$ the City of Johannesburg \& Others (unreported case no 06/13865 in the Johannesburg High Court) paras. 183.4-183.5.

4 Constitution of the Republic of South Africa, 1996.

5 Nqakula C “National Assembly Written Reply to Question 1834, No.43/2007”, 36/1/4/1/200700232, 22 November 2007 Parliament of the Republic of South Africa, Cape Town.

6 Mtshali T "Sloppy municipal management a time bomb" 11 November 2006 SAPA. This mentality is also the preferred position of business; see, e.g., Bernstein A "Sombre messages written in fire" Business Day, 8 May (2007). 
In contrast to the strategy of Muller and Mbeki, which is to avoid central government responsibility for numerous local water crises, the applicants' case argues for a universal shift in delivery practice with national policy implications that, in turn, is inspiring international interest in social resistance to water corporatisation along progressive rights-based lines. The rights-based approach supported by the applicants and their community organisations is not the kind of market-friendly rights regime that, for example, allows water disconnections to poor communities, all the while cloaked in rights-rhetoric. Rather, the rights model ascribed to is one rooted in an understanding of power relations and structural inequalities, ${ }^{7}$ which views the South African Constitution as inherently transformative. ${ }^{8}$ Such a rights-based model understands the Constitution (and South Africa)'s main imperatives to be the advancement of human dignity and the achievement of equality. ${ }^{9}$ According to this approach, outside luxury consumption, water is a social good rather than a commercial good.

At a very basic level, instead of neoliberal commodified water, the applicants seek decommodified water. Simply summarised, 'commodifying' water entails:

- highlighting its role mainly as an economic good

- attempting to reduce cross-subsidization that distorts the end-user price of water (tariff)

- insisting upon $100 \%$ cost recovery on operating and maintenance costs (even if capital investments are subsidised)

- promoting a severely limited form of means-tested subsidization

- establishing shadow prices for water as an environmental good

- solving problems associated with state control of water (inefficiencies, excessive administrative centralization, lack of competition, unaccountedfor-water, weak billing and political interference), and in the process

- fostering the conditions for water privatization.

In contrast, 'decommodifying' water entails:

- assuring that there is a universal free lifeline tariff that allows all consumers to have a decent supply available every day

- valorising the public goods and merit goods associated with water (e.g. public health benefits, gender equity, economic multipliers, environmen-

7 Baxi U "What happens next is up to you: Human rights at risk in dams and development" (2001) 16 American University International Law Review 1507-1529.

8 Dugard J "Judging the judges: Towards an appropriate role for the judiciary in South Africa's transformation", (2007) 20 Leiden Journal of International Law 965-981. The transformative nature of the Constitution is evident in the preamble ('Heal the divisions of the past and establish a society based on democratic values, social justice ...'), the founding provisions (at $\mathrm{s} 1:$ The Republic of South Africa is ... founded on the following values: (a) human dignity, the achievement of equality $\ldots)$, and also in the equality provisions of s 9 , which explicitly sanction positive discrimination in the interests of equity and justice on an individual or collective basis (at s 9(2): "Equality includes the full and equal enjoyment of all rights and freedoms. To promote the achievement of equality, legislative and other measures designed to protect or advance persons, or categories of persons, disadvantaged by unfair discrimination may be taken").

9 Constitution (fn 4 above) s 1(a). 
tal factors and geographical desegregation), which are typically ignored in the private commodity model of water consumption

- imposing a luxury consumption charge on wealthy and over-consumptive households, so as to discourage high volume use (for conservation purposes and to cross-subsidise universal free lifeline water)

- providing legislative and even constitutional protection for consumers so as to realize their "right" to water in a manner that empowers citizens and workers, not bureaucrats.

The difference between the two approaches is partly geographical, because from 2001-06, Johannesburg's water was run by a Paris for-profit supplier, Suez.

\section{IOHANNESBURG WATER, PARISIAN PROFITS}

One reason for global interest in the case is the role of one of the world's largest water management firms. Johannesburg's early-2000s retail water restructuring was mainly influenced by the Paris-based Suez, which controlled the Johannesburg Water Management (Jowam) contractor to the city from 2001-06. Jowam managed the Johannesburg Water (Pty) Ltd., a company established in December 2000 to discharge the City of Johannesburg's water service delivery functions. Although functioning at arms-length from the City, Johannesburg Water is a publicly-owned corporation with the City as its only share-holder. As a public company delivering a public service, Johannesburg Water is bound to discharge all the constitutional and legislative duties including the City's obligations regarding the poor. But until 2006, when the Paris connection was severed (partly because of pressure from aggrieved residents), Johannesburg Water relied on Jowam for global cutting-edge managerial techniques, especially in relation to "demand-side management" of water, which effectively meant limiting consumption by low-income people. Those techniques remain in place in 2008, and have been extended to many other municipalities across the continent, with SA firms like Conlog supplying pre-paid water meters across Africa.

No one would deny that Suez faced severe structural and political problems at the outset of its contract. For example, even before 2000, civil society engagement with Johnnesburg Water and Jowam was tainted. The City of Johannesburg's commercialisation agenda was predetermined to the extent that the ANC metropolitan leadership fired prominent city councilor Trevor Ngwane, head of the regional African National Congress (ANC) in Soweto, when in September 1999 he wrote a newspaper article criticizing the forthcoming water contract. Subsequent public debates and protests included mass labour marches (at one stage in 2000 leading to the mobilisation of 20000 municipal workers) and the rise of a new movement - the Anti-Privatisation Forum (APF) in mid-2000 - just as the contract was formalised. ${ }^{10}$

10 Bond P "Johannesburg's Resurgent Urban Social Movements” in Gibson N (Ed), Challenging Hegemony: Social Movements in Post-Apartheid South Africa and the Quest for a New Humanity (2006) Trenton Africa World Press. 
Beginning its work in 2001, Suez inherited a dysfunctional system in lowincome areas, especially the shack settlements which are home to nearly a third of the city's 3.2 million residents: $65 \%$ use communal standpipes and $20 \%$ receive small amounts from water tankers, while the other $15 \%$ have outdoor yard taps. For sanitation, 52\% have dug pit latrines themselves, 45\% rely on chemical toilets, $2 \%$ have communal flush toilets and $1 \%$ use ablution blocks. Needless to say, these conditions are both particularly hostile to women and children, and breed disease at a time when Johannesburg's HIV rate has soared above $25 \%$ and when cholera and diarrhoea epidemics are still spreading. For Human Development Index comparisons that combine income, education and mortality, Johannesburg's white residents rate 44 , just below the average of rich countries, 45, while the city's black residents rate 32, just above South Africa as a whole. ${ }^{11}$

Instead of expanding supply to these un-served areas, Suez's response to poverty was to take part in massive water disconnections. At peak in early 2002, just before community resistance became an effective countervailing force, Johannesburg officials were disconnecting more than 20000 households per month from power and water. ${ }^{12}$ For municipal bureaucrats and Suez, disconnecting low-income people and maintaining low water/sanitation standards so long after liberation was part of its strategy, quite simply, to save money. Johannesburg managers were also reluctant to offer a genuine free lifeline supply and rising block tariff so as to redistribute water from rich to poor, and simultaneously encourage water conservation. The reason for maintaining relatively low marginal price increases for high volume consumption (and high price increases for consumption from $6-10 \mathrm{kl} /$ household/ month) was to mop up excess water supply created by Lesotho dam cross-catchment water transfers. During the late-1990s, Johannesburg also became liable for the Katse megadam debt repayments to the World Bank and other financiers, resulting in a spectacular 69\% increase from 1996-99 in the nominal cost of water purchased from the Rand Water Board, the bulk supplier of water to Johannesburg Water. By the time the Igoli 2002 municipal corporatisation strategy was established in 1999, Johannesburg's water prices became more financially regressive than during apartheid, but due to a flatter slope in the block tariff, disadvantaging low-income, low-volume consumers.

11 Bond P "Johannesburg: Of Gold and Gangsters" in Davis M Monk D (Eds) Evil Paradises: The Dream worlds of Neoliberalism New York, New Press (2007); Bond P "Johannesburg Infrastructure" in Segbers K et al (Eds) Public Problems, Private Solutions? New Trends from Globalizing Cities in the South (2005) Aldershot Ashgate.

12 Bond P Unsustainable South Africa: Environment, Development and Social Protest (2002) London Merlin Press; Sunday Times Gauteng Metro 19 May 2002. 
However, as discussed in more detail below, a free basic lifeline was promised as national water policy in 2001, amounting to 6,000 liters of free water each month for each household. At the local level such as in Johannesburg, this policy translates to 6kl FBW per account-holder per stand. The DWAF website claims that "100\%" of Johannesburg residents are beneficiaries of the free basic water provision, but this is impossible, given how few low-income people have their own house or yard connection, and given how many people have faced water disconnections due to inability to pay their water bills. ${ }^{13}$ From a progressive perspective, the main pricing debate is whether the free lifeline block (the FBW allocation) is adequate (and fairly administered) and whether, following the FBW zero-rated block, the tariff curve rises in an excessively 'convex' or sufficiently 'concave' manner.

DWAF's national FBW policy derives from the December 2000 municipal elections, which was held in the wake of rising protest and alienation, as well as the cholera epidemic, and was meant to fulfill this promise: "The ANC-led local government will provide all residents with a free basic amount of water, electricity and other municipal services so as to help the poor. Those who use more than the basic amounts, will pay for the extra they use". Johannesburg reinterpreted this otherwise progressive mandate regressively, however, by adopting a relatively steep-rising convex tariff curve, in contrast to a concave curve starting with a larger lifeline block, which would have better served the interests of lower-income residents. In 2003, the second tier of the block tariff (7-10 kl/household/month) was raised by $32 \%$, while the third tier $(11-15 \mathrm{kl} /$ household/month) was lowered by $2 \%$, during a period of roughly $10 \%$ inflation, which was the amount by which higher tier tariffs increased. The dramatic increase in their per-unit charges in the second block meant that there was no meaningful difference to their average monthly bills even after the first free 6000 liters. Moreover, the marginal tariff price for industrial and commercial users of water, while higher than residential, actually declines after large-volume consumption is reached.

Johannesburg's poor residents were hit hard by the price shifts. According to a front page New York Times story in May 2003, Suez officials "acknowledged that in communities like these, billing people for water has been like squeezing water from a stone... Orange Farm women, who live by doing other people's laundry, said they barely had enough money to pay for food and school fees. Many of them already have prepaid electricity meters in their homes, and they say their families end up in the dark for several days each month". ${ }^{14}$ In such a context, with ubiquitous illegal water and electricity connections (the bypass) and after numerous street protests failed, several residents backed by civic groups and progressive lawyers, took Johannesburg to the High Court in a case filed in 2006 and heard in late-2007.

13 Krystall N "Johannesburg's Water Tariff Structure” Masters Research Report University of the Witwatersrand Graduate School of Public and Development Management, Johannesburg (2003).

14 Thomson G "Water tap often shut to South Africa's poor” New York Times 29 May 2003. 


\section{MAZIBUKO \& OTHERS V CITY OF JOHANNESBURG \& OTHERS}

The Phiri application was brought by five unemployed, poverty-stricken residents of Phiri, on behalf of themselves, their households and all residents of Phiri who are in a similar position, as well as everyone in the public interest. The applicants hoped to successfully challenge two specific aspects of Johannesburg's water delivery service, which negatively impact on their lives. First, they sought the option of conventional water meters to replace the pre-paid water meters and, second, they wanted to access sufficient water to cover their basic needs. Through such specific measures the applicants seek, more broadly, to advance a policy reorientation towards viewing water primarily as a social good. Their application has been supported by the Coalition Against Water Privatisation (CAWP), a collection of community organisations struggling against the negative effects of current water services delivery on the poor. The applicants are represented by the Centre for Applied Legal Studies (CALS), a human rights advocacy and public interest litigation centre at the University of the Witwatersrand. The respondents are the City of Johannesburg, Johannesburg Water (Pty) Ltd. and the Ministry of Water Affairs and Forestry.

Starting in March 2004, the applicants, along with thousands of residents of Phiri, were forced to accept either pre-paid water meters or standpipes (outside yard taps) as the only options besides complete disconnection of their previous water supply. The previous water supply, a hangover from apartheid days when municipal officials were more concerned about political activism in Soweto than regulating water consumption, was an unlimited amount of water for which a flat-rate was levied, as though every household consumed $20 \mathrm{kl}$ of water each month. Formally, this 'deemed consumption' system was inequitable in that, regardless of the amount of water consumed, every household was charged the same flat-rate. Informally, the system was acceptable to the residents because, again as a legacy of Soweto's activist past, the municipality neither strictly enforced credit control, nor did it disconnect water as a result of non-payment. From the City's perspective, however, rising arrears and unlimited water consumption became increasingly untenable after 1994, as the imperatives of cost-recovery rapidly overlaid apartheid's imperatives of racism.

So, while households in rich suburbs continued to be able to access as much water as they liked - without any pressure to conserve - for their gardens, swimming pools, fish ponds, baths, and so forth, the City began to target water consumption in Soweto and other 'deemed consumption areas' (townships). To this end, in 2002, the City launched an alternative supply strategy for Soweto, Operation Gcin'amanzi. ${ }^{15}$ This was an "immediate, intensive and comprehensive intervention on a number of fronts" that sought to remedy the problems of "over-supply", lack of "ownership" of water consumption by resi-

15 meaning to "conserve water" in isiZulu. 
dents and "a non-payment paradigm amongst consumers". ${ }^{16}$ Whereas other municipalities had remedied deemed consumption through conventional metering, the City of Johannesburg was determined to ensure that residents of Soweto would not access more water than the FBW amount without first paying for it, instead of getting the additional water on credit the way residents of mainly white neighbourhoods in Johannesburg do. According to its own documentation, Johannesburg Water was "intent on adopting pre-paid water metering as the preferred service delivery option to be implemented in the deemed consumption areas of supply", because "prepayment can be considered to be a water demand management tool" ${ }^{17}$ Demand management was perceived by the City to be critical to the objective of promoting "savings in water purchases by Johannesburg Water [from Rand Water]", ${ }^{18}$ and to the broader goal of improving the financial positions of the City of Johannesburg and Johannesburg Water. ${ }^{19}$

Seeking to 'reduce demand' for water among Soweto residents, as well as to improve the City's financial situation, and without consulting affected residents before taking the decision to rollout pre-paid meters en mass, Johannesburg Water began the bulk infrastructure construction work for the installation of pre-paid meters in Phiri (site of the Soweto pilot rollout) on 11 August 2003. Individual house connections began in February 2004. However, progress was slower than anticipated because of the rising resistance from residents who had heard about the negative ramifications of pre-paid meters from people in Orange Farm informal settlement. ${ }^{20}$ Under the auspices of the APF and community organisations, such as the Soweto Electricity Crisis Committee and Concerned Phiri Residents Committee, spontaneous protests turned into mass action, with many residents simply refusing to allow Johannesburg Water to install the meters. As a result, many residents were left without water at all for many months in 2004. Later, in desperation, most of those who refused the meters were forced into accepting standpipes, which allowed an unlimited supply of water for free (debunking the water conservation front of Operation Gcin'Amanzi) but involved much inconvenience for households because of no longer having an in-house connection, for example, people with standpipes now have to carry buckets of water to flush their toilets, which were not designed for an external water supply.

By the end of 2004 most households in Phiri had been forced to accept either pre-paid meters or standpipes. All were forced to relinquish the previous unlimited water supply, which was discontinued. To sweeten this bitter pre-paid meter pill, Operation Gcin'amanzi was accompanied by municipal

16 Undated report on "Operation Gcin'Amanzi” included in the minutes of Meeting of the Operations and Procurement Committee of Johannesburg Water (27 November 2002) 1 (copy of report with author).

17 Ibid (fn 16 above) 3.

18 Ibid.

19 First and Second Respondents' Heads of Argument, Mazibuko \& Others $v$ City of Johannesburg \& Others. (16 November 2007) para 17.8.

20 While Phiri was the pilot of Operation Gcin'Amanzi in Soweto, pre-paid meters had already been installed throughout Orange Farm. 
debt write-off, contingent on not tampering with the meter, and a publicity campaign around the extension to Phiri households of 6kl FBW supply, as was already being provided through conventional meters to the rich suburbs of Johannesburg. ${ }^{21}$ But there was no sweetening of the bitter effects of pre-paid meters in Phiri, where the majority of residents survive on government grants and cannot afford to spend any money on water. One result of Gcin'amanzi for many households is being without water for days and even weeks at a time every month. With average households of thirteen or more people, many of whom are People Living with HIV/AIDS (PLWHA), the standard FBW is insufficient to meet basic needs. The FBW is allocated per stand (as opposed to per individual), so is biased to smaller households, e.g. white families with fewer children who moved to Johannesburg's proliferating gated communities. As a result, Phiri residents must make undignified and unhealthy choices about basic hygiene and health. For example, carers of PLWHA must choose between bathing their patients or washing their soiled bed sheets, and parents must choose between providing their children with body washes before they go to school or flushing the toilet.

For the many large households in Phiri who exhaust their FBW supply before the end of the month and are too poor to afford additional water credit, the ultimate punishment is the pre-paid meter's automatic and immediate disconnection. Unlike conventional meters in rich suburbs, which provide reasonable warning of a proposed disconnection and an opportunity to make representation (in the form of notification in red writing at the bottom of the monthly bill that the account is in arrears), pre-paid meter disconnection occurs automatically and without warning following the exhaustion of the FBW supply. As a consequence, households are often taken by surprise. If the disconnection occurs during the night or over a weekend when water credit vendors are closed, the household has to go without water until the shops are open again. If the household does not have money for additional water, it must borrow either money or water from neighbours in order to survive. The continuous infringements to dignity and health are serious, for a direct risk to life is posed in the event of a fire, as Paki witnessed.

Regardless of such suffering, it is clear from its submissions in the Phiri case that the City remains overwhelmingly fixated on the "principle of payment". Stressing its financial responsibilities (it is important to note that nowhere in its submissions did the City argue that it does not have the resources to provide poor residents with sufficient and appropriately-administered water), the City relied on an arsenal of financial management-related legislation such as the Local Government Municipal Systems Act 32 of 2000, the Local Government Municipal Finance Management Act 176 of 2004, the Local Government Municipal Property Rates Act 6 of 2004 and the National Credit

21 In the City of Johannesburg FBW is a universal, one-size-fits-all benefit - every account-holder automatically receives the rebate each month as a $6 \mathrm{kl}$ discount on the property's water bill. In other words, if a single rich businesswoman in Sandton uses less than 6000 litres per month, she pays nothing for water even though she is well-placed to afford high water tariffs and she probably consumes more water on a per capita basis than most poor people in Phiri. 
Act 35 of 2005 to suggest that its hands were tied regarding any capacity to do more for the poor. For example, in the course of its legal argument, the City highlighted the stipulation in section 4(1)(c)(i) of the Local Government Municipal Systems Act that the municipality has the right to "finance the affairs of the municipality by charging fees for services". And, in connection with its justification of the rollout of pre-paid meters only to poor areas, the City argued that section 80 of the National Credit Act, pertaining to "reckless credit", precludes the City from entering into conventional credit metered agreements with poor residents in Phiri with large municipal arrears.

Leaving aside the fact, as recognised by Judge Tsoka in the judgement, that in South Africa any constitutional provision, for example the right to equality or the right to sufficient water, will always trump other legislation unless it can be shown to be a limitation of the right that is "reasonable and justifiable in an open and democratic society based on human dignity, equality and freedom", ${ }^{22}$ in advancing this credit control argument the City ignored two critical facts. First, Phiri residents with pre-paid meters have already been granted a debt write-off (an incentive to accept the pre-paid meter). Second, on the City's own admission, the worst debtors in Johannesburg are not the poor, but are "government and institutional bodies whose payment record and responsiveness to credit control measures is poor". ${ }^{23}$ Yet, there is no suggestion that the City plans to impose pre-paid meters on such government and institutional bodies. Tellingly, the City's argument about the rollout of pre-paid meters was often couched in a concern about how much money has already been sunk into pre-paid meters for Soweto (the City continued to rollout pre-paids through the rest of Soweto even after the application was launched). According to this argument, any rights' violations of pre-paid meters should be overlooked in favour of the financial and administrativeconvenience rationales that "if successful, the present application will have enormous adverse implications for the City in that it will fundamentally disrupt the core aspect of the strategic planning of the City and Johannesburg Water" ${ }^{24}$. Put more plainly by Gerald Dumas, the Managing Director of Johannesburg Water, "it is really difficult to conceive of the cost of unravelling some or all of [Operation Gcin'amanzi] in terms of removal of meters, installation of alternative metering sources, and this would seriously impact on Johannesburg Water's finances and sustainability”. ${ }^{25}$ It is worth noting that, in the City's submission, it cost Johannesburg R335 901036.65 to rollout prepaid meters throughout Soweto, ${ }^{26}$ which clearly represents a very substantial investment to protect.

22 Constitution (fn 4 above) $s 36$.

23 Johannesburg Water Business Plans (2003-2005)2.

24 Answering affidavit of Karen Brits, Director: Legal \& Compliance of the City of Johannesburg. (25 January 2007) para 12.1, Mazibuko \& Others $v$ City of Johannesburg \& Others: www.law.wits.ac.za/ cals.

25 Answering affidavit of Gerald Dumas, Managing Director of Johannesburg Water (20 January 2007) para 34, Mazibuko \& Others $v$ City of Johannesburg \& Others: www.law.wits.ac.za.

26 Answering affidavit of Karen Brits, Director: Legal \& Compliance of the City of Johannesburg (25 January 2007) para 27.4.5, Mazibuko \& Others $v$ City of Johannesburg \& Others: www.law.wits.ac.za/ cals. 
In stark contrast to the City's cost-recovery preoccupation, the applicants in the Phiri water rights case approached the issue from a basic needs- and progressive human rights-perspective. Using legal arguments based on the South African rights to water, equality, health, dignity and administrative justice, the application challenges the lawfulness of the pre-paid meters in terms of their failure to provide procedural protections prior to automatic disconnection. Pursuing the same rights-based approach, the application also argues that the City's monthly FBW allocation, which aims to provide each person in a household of 8 with 25 litres of water per person per day, is insufficient to meet the basic needs of urban human beings. It is, therefore, according to the applicants, not a reasonable policy. This is for three related reasons.

First, there is no rational basis for the $6 \mathrm{kl}$ amount, as this allocation is not based on any rational analysis of the quantity of water needed by poor people in various spatial settings to enjoy a dignified existence. Rather, as clarified in the City's pleadings, and particularly the answering affidavit of Neil Macleod, the $6 \mathrm{kl}$ amount is based on an administrative convenience. In his answering affidavit Neil Macleod (Head: Water Sanitation of the eThekwini Municipality) explains how eThekwini's 1997 model of free basic water provision became the basis for DWAF's subsequent national FBW policy. For this reason it is worth outlining the genesis of the eThekwini model, as it reveals a total absence of a rights or needs-based approach to water provision, which was adopted by DWAF, and by the City of Johannesburg, as the national policy without any subsequent needs-analysis. As outlined by Macleod, in 1997, having decided to address the issue of water provision to informal settlements, Durban Metropolitan Council (subsequently re-named eThekwini) found that "approximately 7 litres of water was used per person per day as this was generally the amount that an individual could physically carry and could afford". ${ }^{27}$ Based on this observation, and knowing that the average household contained 7 people, the City began to provide a 200 litre drum at the front door of each shack, which "could be filled once a day with clean drinking water ... at a minimal charge". ${ }^{28}$ However, during 1998, "it became apparent that the amount of money that was collected by the Council for the water supply was in fact equivalent to or less than the costs of administering the collection of the amounts from the relevant communities" and, for this reason, the City began to provide the amount for free. ${ }^{29}$ In summary, the basis of the national FBW policy was a practice by Durban Municipality of providing 200 litre drums of water to each resident of informal settlements (because this approximated the amount they had previously been able to carry each day) without charge because it turned out to be cheaper to dispense the water for free than to administer the billing and payments for it.

27 Answering affidavit of Neil Macleod, Head: Water and Sanitation of the eThekwini Municipality (8 January 2007) para 9, Mazibuko \& Others $v$ City of Johannesburg \& Others: www.law.wits.ac.za/ cals.

28 Answering affidavit Karin Brits (fn 24 above), paras 7-11.

29 Answering affidavit Karin Brits (fn 24 above) para 12. 
The second reason for the applicants disputing the reasonableness of the FBW policy is that it is an inflexible one-size-fits-all policy. In terms of the City's FBW policy, every household in Johannesburg - regardless of size or need - receives $6 \mathrm{kl}$ per month. The applicants argue that this policy automatically discriminates against large poor multi-dwelling households in which everyone has to share the same allocation of water. In Phiri for example, where the average property has more than 8 people (recent research shows that there is an average of 13 people per property in Phiri), each person gets below the 25 litres per person per day.

Thirdly, the application argues that, in any event, 25 litres per person per day - just two flushes of a toilet - is insufficient to meet the basic water needs of poor people. Based on the expert evidence of Peter Gleick, a Californiabased expert on water rights and sufficiency, the application argues that the City should provide 50 litres of FBW per person per day. Gleick and his colleagues $^{30}$ confirm that in conditions such as Phiri, the minimum amount of water to ensure a basic standard of living is 50 litres per capita per day (lcd), broken down as follows:

- Minimum for drinking: $\quad 5 \mathrm{lcd}$

- Basic sanitation: 20lcd

- Basic bathing: 15lcd

- Basic food preparation: 10lcd

TOTAL 50lcd

Notably, the 1994 Reconstruction and Development Programme (RDP) of South Africa's ruling ANC called for a "medium-term" allocation of water of 50-60 lcd. The reality is that in Phiri, many people have to survive on far less than the $25 \mathrm{lcd}$ that the $R D P$ promised as a short-term emergency measure. According to the World Health Organisation (WHO), access to water of below 20lcd carries with it a "high level of health concern" and is insufficient to cover "laundry/bathing unless carried out at source". ${ }^{31}$

For the people of Phiri and their supporters, the case is not only of critical importance in securing access to sufficient water, and procedural safeguards against water disconnections, for poor people. In addition, it represents a challenge to the degradation of the $R D P$ by neoliberal bureaucrats whose national strategies undermined the progressive potential of the ANC, driving it from social-democratic electoral uhuru of April 271994 to the explicitly neoliberal White Paper of December 1994 which made "cost recovery" on water's operating and maintenance costs - and resistance thereto - the underlying logic of so much else that would follow in South African hydropolitics.

30 Gleick P The World's Water 2002-2003: The Biennial Report on Freshwater Resources et al (2000) Washington, DC: Island Press.

31 Of these rights-based arguments, Judge Tsoka focused on the sufficiency argument in his judgment. Accepting Peter Gleick's international expertise (which the City had unfoundedly questioned), the judge ordered the City to provide 50 litres of FBW per person per day to the applicants and others similarly situated in Phiri. 


\section{EXPLAINING WATER POLITICS: MIKE MULLER'S NATIONAL 'PARISH PUMP'}

Who is ultimately to blame for the problems faced in Phiri and hundreds of other similar settings: local or national administrators and policy-makers? To answer properly is a prerequisite for fixing the problems. The strategy of Phiri activists, as part of the national Coalition Against Water Privatisation, is to force a rethink on both technology and water pricing, so that not only Johannesburg Water but all other municipalities are threatened with constitutional cases using water rights, in a manner that also implicates national government so as to compel state policy change.

The question in the water sector, as in so many other areas of social policy, is whether on the one hand existing national policies and legislation are sufficient to deliver the promised goods, and hence problems lie in municipal-scale implementation, which is conventional wisdom (e.g. as promoted by Thabo Mbeki regularly) - or on the other hand, whether the policies and laws themselves require radical change to excise their neoliberal character. Perhaps the most sophisticated version of the former argument is Mike Muller's 2007 article, ${ }^{32}$ whose primary aim appears to be shifting the responsibility for systemic problems to municipal officials.

As the leading water official during the late 1990s and early 2000s, and as someone who has garnered a strong reputation as a critic of explicit privatisation amongst international water professionals, Muller offers a fascinating analysis which, implicitly, addresses the core power relations that surface in the Phiri lawsuit. Muller insists that the South African government has purposively, carefully constructed a development state providing water in the best traditions, combining social-democratic commitments to human rights and construction of an efficient delivery system, notwithstanding potentially dangerous pressures from the right and left, and from municipal incompetence as well as global private profit-seekers. Because it is the strongest analysis to date that would give credence to the state's position, and does so ostensibly from a rights-based perspective, Muller's work deserves careful study. In other words, Muller's analysis appears to us as the most convincing and heartfelt articulation of a rights-based argument on behalf of existing policies. It was no accident that he was recalled to depose to an answering affidavit in support of DWAF in the Mazibuko et al case.

We argue that although Johannesburg Water is not cited in Muller's article, the national policy which he designed and implemented made it logical for the city - and many other South African municipalities - to deny water to poor people. This occurred directly within the scope of Muller's paradigm - DWAF's 1994 Water Supply and Sanitation White Paper, in which he played a central role, especially in insisting upon $100 \%$ recovery of operating/maintenance

322007 Progress in Development Studies journal article "Parish pump politics: the politics of water supply in South Africa". 
$\operatorname{costs}^{33}$ - notwithstanding his stated hostility to the large international water privatisers and a subsequent revision of the policy so as to permit a token FBW allocation. Indeed it is particularly where Muller distances himself from the commodification of water, that a rebuttal is in order, for this process with its necessary corrollary, limitation of water consumption by the poor - is indeed the central cause of the problems faced by Phiri residents.

In his article, Muller locates himself on seemingly sensible, practical middle ground, between extremes ranging from "economists of the neo-liberal schools to the post-Modernists of the global social movements". Indeed, "parish pump politics" is an often derogatory term used to describe the use and, usually, the abuse of local politics focused on practical issues. ${ }^{34}$ But invoking the 'local' as his defense for both successes and defeats, Muller is not without an overarching rights-based rhetoric himself, for he claims to have operationalised the ubuntu philosophy of Water Minister Ronnie Kasrils, whom Muller served from 1999-2004 following the earlier (1994-99) reign of Kader Asmal who then became head of the World Commission on Dams (1998-2001)

33 The 1994 policy insists, "where poor communities are not able to afford basic services, government may subsidise the cost of construction of basic minimum services but not the operating, maintenance or replacement costs" (emphasis added). Department of Water Affairs and Forestry (1994), "Water Supply and Sanitation White Paper", Cape Town, p. 19. This crucial point was repeated in a 1997 revision: "To promote the efficient use of water, the policy will be to charge users for the full financial costs of providing access to water, including infrastructure development and catchment management activities." Department of Water Affairs and Forestry "White Paper on a National Water Policy for South Africa" Pretoria (1997) 4.

34 Muller M "Parish pump politics: the politics of water supply in South Africa" (2007) 7, 1 Progress in Development Studies p.34. We offer one minor clarification about our bias in addressing Muller: it comes not from the alleged 'post-Modernists of the global social movements'. Because post-modernism does not recognise transcendental universal processes such as commodification, decommodification struggles, or social movement formation at the global scale, much less rightsbased rhetorics, Muller early on reveals a tendency to misunderstand and mislabel those outside the water technocracy. Because Muller's commodified water policy and penchant for disconnections caused division and despair (not to mention death), one of the world's strongest anti-privatisation movements arose in South Africa to oppose him. But that movement has regularly advocated socialism and the hydrological trappings of modernity (not post-Modernism): at least 50 liters per person of water each day, a waterborne sanitation system, and human dignity. These water services are denied this movement's constituents by the "economists of the neo-liberal schools", especially World Bank teams which from November 1994 were already setting limits on SA's national infrastructure policy. See Bond (fn 12 above) 2000. Cities of Gold, Townships of Coal, Trenton, Africa World Press. Instead of opposing those economists, Muller graciously implemented their recommendations until circumstances changed in 2000 and, even then imposed a FBW policy that, we argue, undermined water rights rather than secured them. Moreover, Muller (fn 34 above) then argues that 'the antiprivatisers, stung by the challenge that privatisation was not really an issue since only 5 out of 284 municipalities had privatised their water services, conflated the issues of cost recovery for and commodification of water with privatisation. This further confused the issue, since they had, in other contexts, supported cost recovery (from the well-off and from farmers).' In fact, for no SA municipalities suffered formal "privatisation" insofar as water piping and related infrastructure is sold outright to private firms; instead, the all-encompassing commodification of water applied to all 284 municipalities, in large part thanks to Muller's 1994 White Paper. The anti-privatisers correctly saw the commodification process as the first step to municipal commercial subcontracting, and beginning in 1994 with the RDP, called for FBW as one antidote to this process. To get FBW would require, however, that much higher prices be applied to large-volume users ('the well-off and farmers'), so as to effect cross-subsidisation. There is no confusion or contradiction here, except in Muller's own thought processes. To further blame the activists' anti-privatisation discourse, as Muller (fn 34 above) immediately does, upon the "Northern countries" assiduous promotion of environmentally sustainable policies (which provide useful non-tariff mechanisms for promoting their goods, services and other interests)' is simply bizarre. 
and SA Minister of Education (1999-2004). Muller cites Kasrils approvingly: "We do not help the poor because we are charitable. We help them because they are part of us and we are nothing without each other." In that spirit, Muller and his department claim to have "provided access to water-supply infrastructure to over 10 million people" from 1994-2006, notwithstanding barriers including self-serving municipal officials, patronage-oriented politicians and misguided leftist protesters..$^{35}$

These are the essential components of the "Parish pump politics" argument, and compel scrutiny. But the rights talk disguises a central fact: Muller was the most powerful policymaker and manager from 1994-2005, during the time of the country's worst-ever recorded cholera crisis. A spate of disconnections in KwaZulu-Natal Province was at the pandemic's epicentre, although Muller denies the well-documented correlation. ${ }^{36}$ Nevertheless in 2001, Muller conceded on national television that his policy was "too market-oriented", ${ }^{37}$ and, consistent with the African National Congress promise of FBW in the 2000 municipal elections, he permitted a slight adjustment away from the full cost-recovery policy (for operating and maintenance expenses) that he and his colleagues had imposed in the 1994 White Paper. But as argued below, the turn to FBW was not sufficient to ensure that a large proportion of South Africans had their constitutional rights to water met, and in the case of Durban actually led to less affordable water consumed by low-income people in 2004 compared to 1997.

\section{LOCAL WATER DISCONNECTIONS}

Consider the ongoing controversies over water connections and disconnections, which not only have provoked dramatic community protests, but also provided a central reason for Johannesburg Water's adoption of pre-paid (self-disconnecting) meters. It is important to ask, how many South Africans actually got access to water since liberation from apartheid in 1994, and still have it today? Tragically, we simply do not know. No one disputes that tens of thousands of communal water taps were installed by government and its delivery agents, but no one knows how many still operate, as a result of systems

35 Muller (fn 34 above) 40, 34.

36 Muller (fn 34 above) 40-41. According to Muller, "Cut-offs were also linked by critics to outbreaks of diseases such as cholera and typhoid, again highlighting challenges of interpretation and management. The cholera epidemiology suggested that it was spread mainly from person to person in the unhygienic conditions characteristic of poverty, since the epidemic (which had moved down the East African coast over the previous year) spread along lines of communication rather than along water supply lines or rivers." In contrast, a Sunday Times press report (9 October 2000) confirmed "a startling picture emerged of the sequence of events that led up to the [cholera] outbreak around Ngwelezane. Authorities discovered that some areas were still receiving free water in terms of a 17-year initiative of the former KwaZulu government to deal with the 1983/4 drought. "It was eventually noticed, and it was decided to switch off the supply", said the chief executive of the Uthungulu Regional Council, [Mr] B.B. Biyela. "The people were given sufficient warning and the supply was cut off at the beginning of August". The first cases indicating cholera were noticed in Matshana and Nqutshini in the second week of August. The first case confirmed was on August 19." For more, see Bond, P. “The Neoliberal Roots of South Africa's Cholera Epidemic”, in M.Fort, M.Mercer and O.Gish, Sickness and Wealth: The Corporate Assault on Global Health (2004) (Eds) Boston, South End Press.

37 Interview, SABC tv show "Newsmakers”, 14 January 2001. 
that broke due to funding shortfalls for operating and maintenance expenses. Those shortfalls were enormous, because Muller and colleagues set the price of water at the level of full cost recovery in the new government's first water White Paper. Without substantial subsidies, naturally the systems fell apart.

Denying sufficient subsidies to people was one way to effect disconnections. But more explicitly, in October 1995, World Bank water expert John Roome told Asmal and Muller that national government needed to establish "a credible threat of cutting service' to those who were not paying their water bills. ${ }^{38}$ After reviewing the subsequent four years of policy and practice, in 1999 Roome and his Bank colleagues declared that they had been 'instrumental in facilitating a radical revision in South Africa's approach to bulk water management". ${ }^{39}$ One reason such a boast must be taken seriously and also applied to retail water management, was that, as a result of a new, unduly harsh national policy on disconnections, millions of households experienced cuts in municipal water services due to nonpayment.

Muller himself has conceded that in 2003 alone, 275000 households were disconnected from water services at least once due to inability to pay, ${ }^{40}$ which amounts to 1.5 million or more people, and these do not include people whose pre-paid meters ran out at a time of insufficient funds to replenish water supplies (i.e., self-disconnection). Subsequently, in his complicated reinterpretation of these figures for Progress in Development Studies, Muller minimises the survey figures that DWAF and the Human Sciences Research Council produced in 2004:

"When asked 'In the past year how often did you experience interruptions of the water service?', 2.6 percent of respondents reported interruptions 'at least once a month' and a further 15 percent 'several times a year'. However, only 7 percent of interruptions were reported to be 'for non-payment'. Instead, 38.9 percent reported that they were interrupted for repairs and 39.3 percent that 'it just stopped". ${ }^{41}$

There is a big difference between Muller's 2004 interpretation of the DWAF/ HSRC data ( 1.5 million people disconnected in 2003 due to non-payment) and his 2007 revision (roughly 7 million people affected by cutoffs in 2003 but only 500000 for known reasons of non-payment). The figures might be reconciled if some of the 39.3 percent (roughly 2.8 million people) who said they didn't know why there were disconnected were simply unaware of their payment status. Given the chaotic status of municipal billing, especially in Johannesburg, and post offices service delivery deficits in townships, many of which lack street addresses, this is a reasonable hypothesis. The onus is on Muller to provide clearer data if he wants to continue to attack David McDonald's 2001 estimate of one million people disconnected per year, a number that now seems to be $50 \%$ too generous to government. ${ }^{42}$ In short, regarding the crucial claim of

38 Roome J "Water Pricing and Management: World Bank Presentation to the SA Water Conservation Conference”, unpublished paper South Africa 2 October 1995.

39 World Bank "Country Assistance Strategy: South Africa" Washington DC Annex C 1999 p. 5.

40 Muller M “Turning on the taps” Mail\&Guardian, 24 June 2004.

41 Muller 2007 (fn 34 above) 41.

42 Miller 2007 (fn 34 above) 40; McDonald D, Pape J Cost Recovery and the Crisis of Service Delivery in South Africa Pretoria: HSRC and London: Zed Books (2002). 
post-apartheid water delivery, no one knows exactly how many millions would reasonably be subtracted from those who Muller counts as newly connected, for one of the signal failings of DWAF during the post-apartheid era was the failure to embark upon systematic national monitoring and evaluation.

More details show how complicated the problem is. The most reliable sample studies of rural water connections are by David Hemson of the Human Sciences Research Council, who conducted research in KwaZulu-Natal province commissioned by Kasrils. Using the minimalist definition of water access mandated in the RDP, according to Hemson, $57 \%$ of projects were either not working or problematic, because water provision was below required RDP levels..$^{43}$ Hemson's work is cited by Muller - but not these embarrassing statistics. ${ }^{44}$ Moreover, the minimum RDP targets -25 litres per capita per day (lcd) within 200 meters of a household - are short-term (years unspecified). Using the medium-term objective of 50-60 litres per person per day on site, which would be a logical objective after a decade and more of democracy, fewer than $5 \%$ of the projects are probably working to RDP levels. One crucial problem is that the rural water projects were constructed not with these medium-term targets in mind, but with an assumption of permanent supplies of just $25 \mathrm{lcd}$ and relatively stable (not expanding) community populations, resulting in much smaller pipes, lower borehole extraction capacity and a collective water well rather than household connections. These restrictions led to systematic system breakage when residents expected even minimal improvements, and thus broke new pipes or hoses into the water mains.

The national policy favouring disconnections is consistent with the water denial problems faced by Phiri residents, i.e., the neoliberal state's orientation to provision of only the amounts of water that are affordable for consumption without subsidy. ${ }^{45}$ The point, however, is that as municipal protests became more regular during the 2000 s and as self-reconnections occurred by community-oriented plumbers and electricians, the disconnection practice of municipalities such as Johannesburg shifted from explicit cut-offs (with all the political heat that would generate) towards, instead, a far more sophisticated strategy: consumer self-disconnections, via the pre-paid meter.

\section{BLAMING MUNICIPAL MISMANAGEMENT}

Instead of addressing the self-destruction of DWAF water projects, it is far easier to blame consumers for nonpayment, and municipalities for not coping properly with the 'unfunded mandate' burden. That burden is the national expectation that even without sufficient resource transfers, local government could still take on further functions after 2001, including peri-urban and rural

43 Hemson D “Rural Poor Play a Role in Water Projects”, Business Day, 1 July 2003.

44 Muller (fn 34 above) 40, cites Hemson "The Sustainability of Community Water Projects in KwaZulu-Natal” Pretoria: Human Sciences Research Council (2003).

45 Even the FBW allotment costs less to give away free to low-income households, as Durban shows, than to bill them, given the high administrative costs, and assuming that after 6000 liters per month, they pay the full amount including the first 6000 liters. 
water once provided by DWAF. Muller's blame-shifting for national government's policy and financial shortfalls diverts our attention to municipal flaws:

"The emergence of a relatively autonomous form of local government from the pre-1994 political negotiations reflected the residual hopes of minority parties that they could maintain a degree of separate administration. The acceptance of this autonomy by the majority parties reflected, in turn, their democratic inclinations and belief in the importance of popular participation in governance processes, a demonstration of the power of the principle of decentralisation... Given this background, the politics of water services in South Africa has inevitably been dominated by the politics of local government." ${ }^{\text {46 }}$

In fact, the 'elite transition' that South Africa's population suffered included enforced municipal-scale elite pacting under conditions of national elite mistrust, for the simple reason that between verkrampte Conservative Party dominance of many old white local authorities and militant SA National Civic Organisation demands and activism, there were practically no local-level peace deals between white and black struck in the 1990-94 period, with one exception, Stutterheim, but under very dubious circumstances. ${ }^{47}$ National negotiators knew that because urban social movements were a potential ongoing source of radical politics and potential ungovernability, municipal transitions would have to be sharply circumscribed. Hence as the transition unfolded, the interim Constitution and Local Government Transition Act (LGTA) included concessions by the ANC negotiators (demanded by FW de Klerk's team, especially Tertius Delport) that forced white and black municipal leaders into governments of local unity, no matter how distasteful. The techniques included a decisive bias in voting weight given to white-dominated wards, which received an automatic 30 percent of council seats during the crucial 1995-99 period, plus veto power over budgets and zoning decisions with an additional three percent. ${ }^{48}$

Why is this important? Those compromise techniques prevented democratic mechanisms from operating, that otherwise might have decisively rid municipalities like Johannesburg of apartheid officials, laws, mentalities and systems, including those related to water. ${ }^{49}$ It is revealing that for Muller, on the one hand, "The emergence of a relatively autonomous form of local government from the pre-1994 political negotiations reflected the residual hopes of minority parties that they could maintain a degree of separate administration." This is a correct interpretation of the white minority side of the elite pact. On the other hand, turning to the black majority side of the elite deal-making in the next sentence, Muller has a different - rather debatable - interpretation: "The acceptance of this autonomy by the majority parties reflected, in turn, their democratic inclinations and belief in the importance of popular participation in governance processes, a demonstration of the power of the principle of decentralisation." 50

\footnotetext{
46 Muller (fn 34 above) 36.

47 Bond (fn 12 above) 2000.

48 Ibid.

49 Even the name Johannesburg might have been changed to something appropriate - it is the first name of the surveyor of the stolen land, Johannes Rissik, but was maintained for "global branding" purposes.
}

50 Muller (fn 34 above) 36. 
Popular participation was in reality demobilised. ${ }^{51}$ There were far more continuities than change in the prevailing municipal power relations, as a result, and officially-inscribed municipal class apartheid emerged from the slow evolution of local democracy, as witnessed in differential municipal water services. Even the Department of Provincial and Local Government's 1998 White Paper admitted that, as a result of such concessions, "Real transformation has yet to occur.... The compromises reached during the negotiation of the LGTA, such as the delimitation of wards in a manner which skewed representation and the requirement that municipal budgets must be approved by a two-thirds majority, will remain in force until the final phase of the transition." ${ }^{2}$ By the time of the final phase, starting in 2001, the processes of services commodification were cemented, and, as witnessed in Johannesburg, white, upper-class residents could count on nonredistributive systems for water, electricity and other municipal goods. Even the working location of municipal employees - far more workers per capita service lower-density, formerly-white suburbs than townships - reflected the durability of privilege. But in all of this, water provided from the parish pump were, in effect, predetermined in location, quantity, quality and price by the national deal-making. And that deal-making hinged upon the application of neoliberal principles, of which none is more important than correlating consumer prices to costs, and in the process avoiding cross-subsidisation.

\section{PRICING TO MARKET}

Having argued that the easy blaming of municipal victims is not the appropriate way to understand or to rectify South Africa's water problems, we can now turn to the class bias - a bias tolerated in national policy - that permeates the provision of water at municipal level, in large part because of the elite deal-making character of the transition. As even Muller himself concedes, municipal water financing often is typically arranged so as "to avoid tariff increases for the well-to-do". ${ }^{33}$ This is strikingly clear in Durban, the city that originated FBW but that, at the same time, doubled the average price of water (even adjusting for inflation) to its residents over a seven year period, 1997-2004. In Durban, the 1997 level of water consumption by the one third of the city's metered (and regular bill-paying) residents who have the lowest income was $22 \mathrm{kl} /$ household/month. Shortly afterwards, the first FBW strategy was adopted (for just the first $6 \mathrm{kl} /$ household/month) in Durban, but steep increases in price for the next blocks of water were imposed. According to detailed research by Reg Bailey (a leading city official at the time), price increases resulted in average consumption by low-income consumers diminishing to $15 \mathrm{kl} /$ household/month by $2003 .{ }^{54}$

51 Bond (fn 11 above) 2005

52 Department of Provincial and Local Government: "Local Government White Paper" Pretoria (1998).

53 Muller (fn 34 above) 36.

54 Bailey R, Buckley C "Modelling Domestic Water Tariffs", Presentation to the University of KwaZuluNatal Centre for Civil Society' Durban 7 November 2005. The price elasticity for water was, hence, a disturbing - 0.55 - an extremely large impact for what should be a basic need, hence relatively impervious to price change. In contrast, for middle- and high-income consumers, the price rise was higher, but the corresponding decline in average consumption far less. 
One argument that logically follows from this example is that municipalities matter, therefore, Muller is correct that local politics dominate water provision. Yet the opposite is more true: the Durban case informed the national in disturbing ways. In motivating a free supply of (just) 25 litres per person each day, Kasrils couched his justification thus: "It would save money because local authorities would not be saddled with the problem of administering large numbers of small accounts". ${ }^{55}$ Durban was the preferred case study of implementing FBW: not to meet human rights, but rather to save money. In the process, it was implicitly accepted that at 6001 liters of consumption, the first 6000 liters would suddenly also be charged for (not just the additional one liter), so as to now justify sending out the bills to the "large number of small accounts". ${ }^{56}$

In the process, instead of more aggressively cross-subsidising from wealthy households which consumed more water per capita, Johannesburg and other municipalities adopted the pre-paid meter, VIPs, shallow sanitation and related techniques - with national consent - so as to disincentivise further use of water by low-income people. As Trengove remarked to the court: "Rich people are given the luxury of using water first and paying later... Discrimination between the rich mostly white residents on the one hand, and the poor mostly black residents on the other, is sheer discrimination on grounds of poverty and race." ${ }^{57}$

The national reasons for these municipal water inequities can be found in the 1994 White Paper, in cost-recovery and pro-disconnection regulations, and in the late 1990s defunding of old homeland municipalities which received national water grants. Yet Muller, like Mbeki, would rather blame municipal personnel for patronage politics:

"In new municipalities, the battle has been to control personnel and procurement decisions. These political battles delayed or even paralysed development projects [because they]... could, and often did, mean people who could help particular interest groups to take control of public resources for private benefit... [or] less qualified or often completely unqualified candidates [gained municipal jobs]... Lack of capacity to take water projects through to implementation was still cited as a reason for the systemic failure of municipalities to spend their resources effectively." 58

The reality, however, is that Muller's DWAF had vast powers that were not exercised: to regulate and to declare "water emergencies" where systemic disconnections or underinvestment occurred (according to the National Water Act of 1998). As Kasrils himself promised in his June 2003 budget speech to parliament, "I will name and shame municipalities that fail to implement Free Basic Water.” But he never did prior to becoming minister of intelligence

55 Business Day, 11 February 2000.

56 The same logic applies to the Pretoria suburbs where wealthy state officials live, as even Trevor Manuel conceded in discussing the Phiri case in the Mail\&Guardian: "Wim Trengove spoke about an inequality of use between living like this [he gestures at his treed garden where hadedas call and a swimming pool laps gently in the morning breeze] and people who battle to find water to wash. But if you've got four or five families living in the backyard, water will run out in the first week." Manuel $\mathrm{T}$ "Not in my father's house: Polokwane Briefing”, Mail\&Guardian, 13 December 2007.

57 Sapa 'Residents "were bullied into accepting prepaid meters” 3 December 2007.

58 Muller (fn 34 above) 37. 
in 2004, where ironically, one of his tasks was to investigate the upsurge of municipal service delivery protests. ${ }^{59}$

\section{SANITATION WITHOUT WATER}

To illustrate government's desire to limit water consumption by poor people, a vast project could have been launched to improve sanitation, but instead practically nothing was achieved in the new government's first five years. DWAF used that period to extend low-volume water supplies in rural areas, with insufficient piping and supply to justify waterborne sanitation. There was no policy for a revamped urban sanitation system defined with national standards. For this reason, low-quality sanitation strategies were adopted within municipalities like Johannesburg.

Suez began installing a new 'shallow sewage' system as well as 6,500 pit latrines between 2003-05. Shallow sewage systems are attractive to the company, because maintenance costs are transferred to so-called 'condominium' residential users, where a very small water flush and slight gravity mean that the pipes must be manually unclogged every three months (or more frequently) by the residents themselves. ${ }^{60}$ But eco-blowback would inevitably result from this kind of urban and peri-urban penny-pinching, as Kasrils admitted to parliament in 2001: "Unacceptable sanitation services resulting in severe water pollution, especially bacteriological pollution, is a grave concern in Gauteng... A lack of funds has been identified as the hindering factor in the upgrading and maintenance of sewerage networks". ${ }^{61}$

These problems would worsen dramatically in subsequent years, leading by early 2008 to national concerns of a water/sanitation crisis borne of the same maintenance shortfalls that led to widespread electricity load-shedding. Muller recognises the sanitation crisis, acknowledging that "the expansion of services to the unserved is slowing" because "The weak conditionality in the Division of Revenue Act (National Treasury, 2006), which regulates the municipal transfers, now has clear incentives for municipalities not to extend services to the unserved." ${ }^{62}$ Again, a national strategy would have solved this problem at the outset, by penalising municipalities which did not have sanitation plans for all residents, in terms of the National Water Act's emergency provisions.

59 www.dwaf.gov.za/Communications/PressReleases/2003/BUDGET\%20Press\%20Release\%20version \%203.doc, accessed 23 February 2008.

60 In this case, Suez tells customers to: "Wear gloves; remove all solids and waste from the inspection chambers; do a mirror test for each chamber-to-chamber section; if waste material is found in a section, bring in the tube from the upstream inspection chamber until it comes into contact with the obstruction; block off the outlet from the downstream inspection chamber with a screen that allows water to pass through but not solids; push the tube until the material is moved to the downstream inspection chamber; wear gloves and remove waste material by hand; pour a large quantity of water through the section between the two inspection chambers and check for cleaning; repeat the mirror test; close the inspection chambers". For more, see Harvey E "A critical analysis of the decision to corporatize the water and wastewater services in the City of Johannesburg", Masters Dissertation, University of the Witwatersrand Graduate School of Public and Development Management, Johannesburg (2003).

61 The Star, 14 May 2001.

62 Muller (fn 34 above) 39. 


\section{A TRICKLE OF FREE BASIC WATER}

The power of the national state in such circumstances is evident when we consider FBW. According to Muller, "One way to ensure that public funds achieve their intended purpose after fiscal decentralisation is through policy". An example of this has been the introduction of a policy of "free basic water" (FBW), in the terms of which every household should receive 6,000 litres of water per month free. Any use above this should be paid for. Muller then notes that this policy cuts against the grain of the commodification strategy associated with globalisation and privatisation: "Conventional wisdom amongst international donors had been that all water consumption should be paid for." 63

Yet the way FBW was implemented contradicted the spirit of a rights-based approach. In telling this story - also a subject of much dispute in the Phiri court case - Muller distorts history:

"The 'free basic water' policy was a fundamental shift from the 1994 policy of the African National Congress (ANC) government. The ANC's Reconstruction and Development Programme had avoided promising the 'pie in the sky'. Its approach to water services was conservative, warning that all would have to pay something, talking of 'a lifeline tariff to ensure that all South Africans are able to afford water services sufficient for health and hygiene requirements' and 'in rural areas, a tariff that covers operating and maintenance costs of services" ${ }^{64}$

In reality, matters were much more complex. In early 1994 a vigorous debate was held (involving Bond, who was one of the RDP Final Editorial Committee members, representing the SA National Civic Organisation) about how to phrase the water promise. Muller, based at the neoliberal Development Bank of Southern Africa, led a small but powerful clique of rural water technical service providers. His insistence on full cost recovery of marginal costs in rural areas is reflected in the phrasing above; in contrast, the urban civic movement's demand for cross-subsidisation and a "lifeline" supply reflected the assumption that free water should be provided. Tellingly, Muller does not recount this component of the RDP mandate (2.10.6.2): "in urban areas, a progressive block tariff to ensure that the long-term costs of supplying large-volume users are met and that there is a cross-subsidy to promote affordability for the poor" (emphasis added). Nor does he recall the RDP's insistence (2.6.7) that the water subsidy for all South Africans should cover "an on-site supply of 50-60 litres per capita per day of clean water" in the "medium-term", which is, at minimum, the length of time that any water/ sanitation infrastructure (capital investments) should cover.

The debate continued in the new government, when Asmal replied to a demand that he respect the RDP promise of a 50 litre per day lifeline supply of water as follows:

"The positions I put forward are not positions of a sell-out, but of positions that uphold the policy of the South African government and the ANC ... The RDP makes no reference to free water to the citizens of South Africa. The provision of such free water has financial implications for local government that I as a national minister must be extremely careful enforcing on local government." 65

63 Ibid.

64 Miller (fn 34 above) 40

65 Asmal K "Policy Directions of the Department of Water Affairs and Forestry" Letter to Patrick Bond Pretoria 8 May 19981. 
It took a leap of logic to redefine the word "lifeline" to mean, not free, but instead the equivalent of the operating and maintenance costs, in other words, full marginal-cost recovery, namely the break-even cost of supplying an additional unit of the water to the customer. Muller argues that matters changed only in 2000 because Free basic services were part of the government's response to debates about social welfare policy. Anxious to avoid the cost and the creation of a culture of dependency, the ANC opted to promote the "social wage" concept, which included free basic water. This is myth-making, for in early 2000, not only did Kasrils announce free water on grounds that "It would save money because local authorities would not be saddled with the problem of administering large numbers of small accounts", as noted above. There were also a variety of other crucial factors that converged to give content to water rights talk:

- growing alienation and apathy in townships, along with declining activity in ANC branches, leading to fears that substantial voter abstention would lower the ruling party's overall vote and cost it control in key municipalities;

- the massive outbreak of cholera, which attracted international attention and undermined popular faith in the water system (even in the cities, where fears of contagion soon emerged);

- Mbeki's bizarre public allegation, at the time of the July 2000 International Aids Conference in Durban, that "HIV doesn't cause Aids, poverty causes Aids", which required a rapid, face-saving backtrack, i.e., addressing poverty by giving away a few drops of free water;

- the imminent October 2000 Grootboom decision in the Constitutional Court, ${ }^{66}$ which signalled that the Constitutional Court might finally enforce the socio-economic rights' provisions in the Constitution (Irene Grootboom and her community in Wallacedene, in the Western Cape, won insofar as the City of Cape Town's housing plan was declared unconstitutional for failing to provide emergency shelter and services for the poorest and most vulnerable members of society); and finally,

- a dawning realisation that the neoliberal water pricing policy was causing more costs than benefits for the society as a whole, and certainly for DWAF's reputation.

The point, again, is that because national policy (determined in large part by Muller) failed so decisively to deliver this crucial rights-based mandate, the Phiri residents now find themselves in court to have their legitimate demands met.

\section{CONCLUSION: THREAT OF - OR HOPE FOR - POPULISTS AT THE PARISH PUMP?}

South Africa's poor people suffer a kind of water apartheid, and to end it requires more than the strategies that have to date been adopted by the post-apartheid state. The core argument by Thabo Mbeki, Mike Muller and other status quo commentators is that existing neoliberal policies are fine, but local implementation is to blame for delivery crisis. Of course, as we have seen in the Johannesburg case,

66 Government of the Republic of South Africa \& Others v Grootboom \& Others 2001 (2) SA 46 (CC). 
local parish politics can indeed be held responsible for widespread South African water failures, particularly insofar as municipal power relations often reflect the way power is established and exercised at national scale.

But as the Phiri residents are attempting to prove in their municipally-specific but nationally-relevant case, overcoming local demand-side management techniques such as pre-paid meters, not to mention shallow sanitation, Ventilated Improved Pit-Latrines and other discriminatory technologies which deny low-income people water, and an exceedingly small municipal FBW supply require systematic national policy change. Pre-paid meters should be nationally outlawed as a health hazard, as they are in Britain. A much larger FBW supply - at least 50 liters per person per day - is required. On offer from Johannesburg, a few weeks before the case was heard, was only one concession: a means-tested shift from $6 \mathrm{kl} / \mathrm{hh} / \mathrm{month}$ to $10 \mathrm{kl} / \mathrm{hh} / \mathrm{month}$ on condition of proof of indigency. Yet much of the benefit of this concession was soon under threat. Over the Easter weekend at the end of March 2008, the print media announced that the City of Johannesburg plans to revise its FBW policy. ${ }^{67}$ In terms of these proposals, ${ }^{68}$ the City plans to withdraw FBW allocations (and also Free Basic Electricity allocations) from all households except those on the indigency register. ${ }^{69}$ If implemented, these proposals will entrench conditions of socio-economic depravation in poor communities, and particularly in the poorest and most vulnerable households, which will struggle to successfully register for benefits. Nor do the proposals reflect a substantive shift away from a cost-recovery driven water delivery paradigm.

67 The Star "Joburg water, power shock" 24 March 2008.

68 The City's proposals were open to public comment for the month of April 2008: www.joburg.org.za. If adopted, the proposals are scheduled to come into effect on 1 July 2008.

69 There are fundamental problems with tying a socio-economic benefit to a means-tested register such as the City's indigency register. First, this approach stigmatizes the poor, reducing them to secondclass citizens who do not fit into the normal contractual model. Second, Johannesburg's indigency register is not well publicized (for example, it does not even appear on the City's official website and, to date, the register has not been widely publicized across poor communities), so most poor households are not aware of it. Third, according to the current policy, acceptance onto the register is means-tested, requiring the applicant to provide proof of: being an account-holder (meaning that it is aimed at property-owners rather than tenants, who on the whole do not hold municipal accounts); having a combined monthly household income of less than twice the maximum government grant plus R1 (currently R940 × $2=\mathrm{R} 1880+\mathrm{R} 1=\mathrm{R} 1881$ ); as well as furnishing positive formal identification, proof of earnings and tax status. Fourth, and most importantly from a poverty-targeting perspective (and related to the above reasons), Johannesburg's indigency register is hopelessly under-representative of the actual number of poor households, meaning that any benefit linked exclusively to the register will only reach a fraction of the formally qualifying poor households. The extent of the under-representation of Johannesburg's poor on the current register was acknowledged in the answering affidavit of Rashid Seedat, Director of the Central Strategy Unit within the Office of the Executive Mayor of Johannesburg. (22 January 2007), Mazibuko \& Others $v$ City of Johannesburg \& Others: www.law.wits.ac.za/cals. At paragraph 31.4 .2 of his affidavit, Seedat states that, as of 31 March 2006, the City's indigency register reflected 118000 indigent households. However, according to information extrapolated from Statistics South Africa's 2001 Census (www.statssa.gov. $\mathrm{za} /$ census01/html/default.asp), as well as the City's Human Development Strategy of 2005 (www. joburg.org.za/content/view/744/114/), there are an estimated 500000 households in Johannesburg that earn between R0 and R1 600 per month (meaning that they formally qualify as indigent). This means that, a decade after its establishment (the indigency register was started in 1998), the City's indigency register captures and administers benefits to only approximately a fifth of qualifying indigent households. It is therefore a wholly inappropriate mechanism for poverty alleviation, especially if it is to become the City's only or main mechanism to allocate benefits to the poor. 
Indeed, the proposals are premised on the view that poor people are aberrations to the normal contractual water supply paradigm, and should be forced to prove their poverty before they can receive any benefits.

Muller concludes his article by expressing concern about populists' "effort to build international coalitions between green interests, progressive political movements, anti-poverty groups and rural activists. Unfortunately, the energy of these campaigns is not matched by the vigour and rigour with which they tackle the larger and more serious challenges of public organisation and sustainability in the water sector." 70 Frightened as Muller might be about growing civil society alliances, the reader can be the judge about which social forces have the vigour, rigour, self-interest and civic commitment to improve the public sector's performance. What the struggle between commodification and decommodification requires, it should be clear, is to connect the dots such that red (social justice) and green (conservation) objectives can be met at the same time and at both local and national parish pumps. Only then, together not apart, can both social and environmental justice be achieved. ${ }^{71}$

\section{BIBLIOGRAPHY}

Asmal K "Policy Directions of the Department of Water Affairs and Forestry" Letter to Patrick Bond Pretoria, 8 May (1998).

Bailey R and C Buckley "Modelling Domestic Water Tariffs" Presentation to the University of KwaZulu-Natal Centre for Civil Society Durban 7 November (2005).

Baxi U "What happens next is up to you: Human rights at risk in dams and development" American University International Law Review 16 (2001) pp 1507-1529.

Bernstein A "Sombre messages written in fire” Business Day, 8 May (2007).

Bond P (2000) Cities of Gold, Townships of Coal, Trenton Africa World Press (2000).

Bond P Unsustainable South Africa: Environment, Development and Social Protest London Merlin Press (2002).

Bond P (2004) "The Neoliberal Roots of South Africa's Cholera Epidemic" in M.Fort, M.Mercer and O.Gish (Eds), Sickness and Wealth: The Corporate Assault on Global Health Boston South End Press (2004).

Bond P "Johannesburg Infrastructure", in K Segbers et al (Eds) Public Problems, Private Solutions? New Trends from Globalizing Cities in the South, Aldershot, Ashgate (2005).

70 Muller (fn 34 above) 43.

71 Ibid. Muller's last words are telling: "The same groups that oppose public investment in new dams (which provide urban and rural areas alike with water security) also oppose restrictions on water consumption under the slogan 'break the meter, enjoy the water'. They oppose the commodification of water, yet call for water for the poor to be subsidised by increasing the prices to the well-off. It is a crude politics that has so far gained little resonance - although the dangers of populist politics lie ahead for South Africa." 
Bond P "Johannesburg's Resurgent Urban Social Movements" in N.Gibson (Ed) Challenging Hegemony: Social Movements in Post-Apartheid South Africa and the Quest for a New Humanity Trenton Africa World Press (2006).

Bond P "Johannesburg: Of Gold and Gangsters" in M Davis and D Monk (Eds) Evil Paradises: The Dreamworlds of Neoliberalism New York New Press (2007).

Brits K "Answering affidavit" Legal \& Compliance of the City of Johannesburg 25 January, in Mazibuko \& Others $v$ City of Johannesburg \& Others: www. law.wits.ac.za/cals (2007)

Department of Provincial and Local Government (1998), Local Government White Paper, Pretoria (1998).

Dugard J "Judging the judges: Towards an appropriate role for the judiciary in South Africa's transformation” Leiden Journal of International Law (2007) 20 pp 965-981.

Dumas G "Answering affidavit" Johannesburg Water 20 January (2007), in Mazibuko \& Others $v$ City of Johannesburg \& Others: www.law.wits.ac.za/ cals

Gleick P et al The World's Water 2002-2003: The Biennial Report on Freshwater Resources Washington DC: Island Press (2002).

Government of the Republic of South Africa \& Others $v$ Grootboom \& Others 2001 (2) SA 46 (CC).

Harvey E "A critical analysis of the decision to corporatize the water and wastewater services in the City of Johannesburg" Masters Dissertation, University of the Witwatersrand Graduate School of Public and Development Management Johannesburg (2003).

Hemson D "Rural Poor Play a Role in Water Projects” Business Day 1 July (2003).

Hemson D "The Sustainability of Community Water Projects in KwaZuluNatal” Pretoria Human Sciences Research Council (2003).

Krystall N “Johannesburg's Water Tariff Structure,” Masters Research Report University of the Witwatersrand Graduate School of Public and Development Management Johannesburg (2003).

Manuel T "Not in my father's house: Polokwane Briefing” Mail\&Guardian 13 December (2007).

Mazibuko \& Others $v$ the City of Johannesburg \& Others (unreported case no 06/13865 in the Johannesburg High Court)

McDonald D and Pape J Cost Recovery and the Crisis of Service Delivery in South Africa Pretoria: HSRC and London: Zed Books (2002).

Mtshali T "Sloppy municipal management a time bomb” 11 November, SAPA (2006).

Muller M “Turning on the taps” Mail\&Guardian 24 June (2004). 
Muller M "Parish pump politics: the politics of water supply in South Africa" Progress in Development Studies 71 (2007).

Roome J "Water Pricing and Management: World Bank Presentation to the SA Water Conservation Conference” unpublished paper South Africa 2 October (1995).

Nqakula C "National Assembly Written Reply to Question 1834, No.43/2007", 36/1/4/1/200700232, 22 November Parliament of the Republic of South Africa Cape Town (2007).

The Constitution of the Republic of South Africa, 1996.

The Star "Joburg water, power shock" 24 March 2008.

Thomson G "Water tap often shut to South Africa poor" New York Times 29 May (2003).

World Bank Country Assistance Strategy: South Africa Washington DC (1999). 